\title{
INFECÇÕES HOSPITALARES NO BRASIL. AÇÕES GOVERNAMENTAIS PARA O SEU CONTROLE ENQUANTO EXPRESSÃO DE POLÍTICAS SOCIAIS NA ÁREA DA SAÚDE.*
}

Rúbia Aparecida Lacerda ${ }^{\star \star}$

\begin{abstract}
LACERDA, R.A. Infeç̧oes hospitalares no Brasil. Açð̄es governamentais para o seu controle enquanto expressão de políticas sociais na área da saúde. Rev.Esc.Enf.USP, v.29, n.2. p. 226-27, ago, 1995.
\end{abstract}

A autora estuda a evolução das infeccoess hospitalares no Brasil e as demandas para o seu controle até a sua institucionalização, por ações governamentais. Para a compreenão e análise do processo de disputa dos interes. ses e necessidades dos atores sociais e sua relação com o setor governamental para a institucionalização de uma dada politica pública buscou-se um referencial teórico que possibilitasse elaborar o conjunto dos elementos da estrutura social e que tomasse o campo da relação entre Sociedade. Estado e Políticas Sociais como sua questão central. Por referencia a especificidade dessas ações e seu raio de intervenção. foi necessário buscar tambem a dis. tinção de modalidades de políticas públicas e a responsabilidade de implementação. $\Lambda$ partir do material empírico, foi possível delincar essas demandas, conformando-as en modelos teeno-assistenciais, atraves de indicadores do processo de trabalho. Sua aproximaça com o referencial teorico exigriu outros níveis de categorias: conjunturas especificas, assistência medica previdenciária, modelo clínico de intervenção e o movimento de qualidade. $\triangle$ análise das demandas e do projeto institucionalizado buscou. o tempo todo, a relação dos seus instrumentos e finalidades com eles mesmos e com as políticas mais gerais do setor saúde. mostrando as suas implicaçós.

\footnotetext{
* Tese de Doutorado apresentada à Escola de Enfermagem da USP, maio. 1995.

** Professor Doutor do Departamento de Enfermagem Médico-Cirúrgica da Escola de Enfermagem da USP.
} 
LACERDA, R.A. Hospital infections in Brasil. Governmental actions for this control as social politics expression in health sector. Rev.Esc.Enf.USP. v.29, n.2, p. 226-27, aug, 1995.

The author studies the hospital infections evolution in Brasil and the demands for its control until its establishment by governmental actions. For a better understanding and analysis of the social actors' dispute process. their needs and interests and the relation with the governmental sector to the establishment of a certain state politics, a theoretical reference that enabled to elaborate the whole of social structure elements was searched. This theoretical reference should also take the filled of the relation between Society. State. Actors and Social Polities as its main question. In order to allude to these specific actions and its intervention range, it was necessary to make a distinction between the state politics modalities and the implementation responsabilities. Based on empirical material, it was possible to trace these demands. conforming on technological-assistencial models through the working process indicators. Other empirical categories levels was demanded to approach to the theorietical reference: specific conjectures, welfare medical assistance, the clinical intervention model and the quality movement. All the time. the analysis of the demands and the stablished project aimed the relation between the instruments and their purposes with themselves and with the health sector general polities, showing its implications. 